\title{
Kéretlen e-mailek az orvos postafiókjában: ezek veszélyei az egészségnevelésre, a betegtájékoztatásra és a tudományos munkára
}

\author{
Felkai Péter dr. ${ }^{1}$ - Lengyel Ingrid $d r^{2}$ \\ ${ }^{1}$ Debreceni Egyetem, Orvostudományi Kar, Belgyógyászati Intézet, Anyagcsere-betegségek Tanszék, \\ Utazásorvostani Tanszéki Csoport, Debrecen \\ ${ }^{2}$ Semmelweis Egyetem, Általános Orvostudományi Kar, Magatartástudományi Tanszék, Budapest
}

\begin{abstract}
Bevezetés: A „spam” (ejtsd: szpem), azaz a levélszemét fogalma azokra a kéretlen elektronikus levelekre utal, melyek valamilyen reklámüzenet formájában próbálnak valamilyen terméket eladni a címzettnek. A világ összes elektronikusan küldött levelének 80\%-a spam, és ez az arány nemcsak a termékek eladását szolgáló, de az egészséget érintő kérdésekben is egyre növekszik. Ez utóbbiakat a szerzők két részre osztják: a laikusokat, illetve az orvosokat és a tudományos kutatókat célba vevő levélszemétre.

Módszer: A szerzők az egy éven keresztül kapott 12986 kéretlen levél alapján a következőket állapították meg: ha az egészséggel összefüggő spamek százalékos részesedését nézzük az összes levélszeméthez viszonyítva, sajnálattal állapíthatjuk meg, hogy az egészséggel összefüggő témájú kéretlen ajánlatok a második leggyakoribb spamfajták (27\%) a különféle használati cikkek vásárlását szorgalmazó spamek (63\%) után, messze megelőzve a többi szolgáltatást és tudományos témát ajánlgató leveleket.

Eredmények: A lakosság egészségét célba vevő spamek között a legveszélyesebbnek tekinthető a laikusok részére küldött gyógyítási ajánlat (31\%). Az egészséget érintő egyéb spamek közül a különböző szerek orvosságként való javallata 19\%, a szexuális diszfunkció kezelésére ajánlott szerek 11\% volt. A szakemberek számára küldött spamek az összes levélszemét 4\%-át tették ki, köztük áltudományos újságok számára kért cikkek 68\%-ban, különböző gyanús kongreszszusokra való felhívás $27 \%$-ban szerepelt.

Következtetés: A spamek veszélye abban rejlik, hogy gyakran olyan egészségi problémák megoldását ígérik a laikusoknak, melyeket a jelenlegi orvosi ténykedések nem tudnak a beteg számára kielégítően gyógyítani (onkológiai, mozgásszervi, anyagcserezavarok stb.). Ezáltal nemcsak becsapják a reménykedő betegeket, de egyúttal - hatékonyságuk miatt - a betegek felvilágosítását, az egészségnevelési tevékenységet is nagymértékben rombolják. Ezen egészségügyi csalások ellen a jog eszközeivel még hatásosabban kellene fellépni, és még hatásosabb, szakmailag korrekt betegtájékoztatási módszereket szükséges kidolgoznunk. Orv Hetil. 2019; 160(43): 1706-1710.
\end{abstract}

Kulcsszavak: spam, egészségnevelés, egészségügyi felvilágosítás, betegtájékoztatás, internet, levélszemét

\section{Spams in doctors' mailbox: their threat to health education, to patient information and to scientific research}

Introduction: The term "spam" is applied to unwanted commercial e-mails sent to all whose e-mail addresses have been acquired by the spammers. The number of undesirable e-mails is growing in the health-care related areas as well. The targets of health-care related spams are laymen, physicians and academic researchers alike.

Method: On the basis of 12,986 unwanted letters received in one year, the authors concluded that percentage of health-related spam is the second most common spam (27\%) in relation to all spam. Most of the spam (63\%) aggressively promoted purchasing of various consumer goods, but health-related spam are far ahead of the rest. The collected data were grouped by year and topic and they are analyzed by simple descriptive statistics. Spam form of cyber attacks on health care issues were divided into two: spam what is jeopardized individuals' health (e.g. medical compounds without any curing effect, misleading statement on medical device, fraudulent panacea offers, and cheating 
cure methods, etc.) and onslaught on medical scientific activity (pseudo-scientific congress invitation, predator journal invitation etc.).

Results: The topics of spams addressed to laymen are offered for perfect healing by strange treatments, cures (31\%), panaceas (19\%), lifestyle advice (19\%), massage (16\%), brand new health-care devices (4\%) and drugs for sexual dysfunction $(11 \%)$. The topics of spams addressed to physicians and researchers are deluged by pseudoscientific materials: invitation for articles to be sent to no-name/fake open-access journals (68\%), invitation to participate at an obscure congress $(27 \%)$ or newsletters on miscellanous medical topics $(5 \%)$.

Conclusion: The spams offer very often relief or solution to medical problems that the present-day medical practice cannot solve perfectly (oncological, musculo-sceletal, endocrin or metabolic problems). Understandably, the patients would hold on to fake hopes - and the authentic patient education and health promotion will be neglected. These unwanted messages practically cannot be unsubscribed, and - while the spam filters are far from perfection - the victim must go through the filtered spam-dustbin in order not to miss some real messages. Unfortunately no legal regulation (neither local, nor GDPR) can block or stop the spams. The spams are misleading the laymen and jeopardise the effects of professional and responsible health promotion and health education.

Keywords: predatory journal, spamming, e-mail, cyber threats, health education, health promotion, internet, cyberpiracy

Felkai P, Lengyel I. [Spams in doctors' mailbox: their threat to health education, to patient information and to scientific research]. Orv Hetil. 2019; 160(43): 1706-1710.

(Beérkezett: 2019. május 15.; elfogadva: 2019. június 14.)

\section{Rövidítések}

GDPR $=($ General Data Protection Regulation $)$ európai általános adatvédelmi rendelet; OTC $=($ over-the-counter $)$ vény nélkül kapható

Napjaink elektronikai információs forradalma változásokat hozott az egészségügyben is. A betegnyilvántartásnak és -adminisztrációnak, a képalkotó vizsgálatok rögzítésének, a beteg- és szakember-tájékoztatásnak, a graduális és posztgraduális oktatásnak az internetalapúvá tétele gyorssá és egyszerúen elérhetővé tette ezeket a szolgáltatásokat. De, mint minden haladást szolgáló módszernek, az internet használatának is megvan a maga árnyoldala: az új lehetőségekkel való visszaélők széles köre is kialakult.

Az új technológia felhasználásának nehézségeire jó példa az Európai Unió új adatvédelmi irányelvének (General Data Protection Regulation - GDPR) bevezetése, melynek elöírásai sok helyen ellentétben vannak a magyar egészségügyi adminisztrációt előíró jogszabályokkal; a visszaélésekre sajnálatos példa a számítógéphez való hozzászokás [1], az ostoba, felelótlen és csak a vásárlásra buzdító weboldalak és kéretlen elektronikus levelek (spamek) áradata. Megbízható és szakmailag helyes honlapot találni még a szakembernek sem könnyú.

A betegek - nem csak hazánkban - ódzkodnak az orvos felkeresésétől, helyette környezetüket, a hasonló tüneteket már átélt betegtársakat vagy az általuk hitelesnek tartott személyt kérdezik meg - orvoshoz fordulás helyett. A nemzetközi felmérések ezen a téren döbbenetes tényeket tárnak fel: például a sérült sportolóknak csak 11\%-a fordul elsőként orvoshoz, 57\%-uk máshonnan, föként az internetről szerzi be a jó tanácsot [2]. Az utazás- hoz szükséges egészségügyi információkat az utazók 49\%-a laikustól, ezen belül 19\%-a az internetról szerzi be [3]. Sajnálatos módon az internetes információszerzés világszerte probléma, és a szakmai körök már az internet elterjedésekor is igen ártalmasnak tartották [4]. Ijesztő, hogy még a fejlett egészségüggyel rendelkező országokban is minden második ember az interneten keresi az öngyógyítás lehetôségét [5]. Gyakorló orvosok szembesülnek a betegtôl származó felelősségre vonással, miszerint a bajukra az interneten nem ezt a gyógymódot/ gyógyszert javasolták. Erre a jelenségre az interneten keresztül vásárolható gyógyszerek és a megtévesztő hirdetések még rá is játszanak [6]. Magyar szerzők az egészségügyi felvilágosítással foglalkozó weboldalakat vizsgálva azoknak csak a 0,8\%-át találták hitelesnek. Felismerve az információ adás/szerzés e könnyü és hatásos módját, a spamküldő kereskedők gátlástalanul kihasználták a helyzetet.

Az internetet használó betegek nemcsak ismeretszerzés, hanem az orvos-beteg interakció lerövidítése és egyszerúsítése céljából böngésznek a különböző oldalakon. A keresőprogramok ezt kihasználva a felugró hirdetések által nyújtott, sokszor az adathalászat révén személyre szabott egészségügyi tárgyú hirdetéseket kínálják a felhasználónak. A beteg, aki megkapja - vagy legalábbis úgy véli, hogy megkapta - a számára fontos és szükséges tájékoztatásokat, már nem kérdez az orvossal való találkozás során, ha egyáltalán ezután orvoshoz fordul. Ez a magatartás az egészségére nézve sokszor téves, egészségkárosodáshoz vezetô következtetés levonásához vezet.

A hazai betegtájékoztatás részletességét és individualizáltságát az egészségügyről szóló 1997. évi CLIV. törvény szabályozza, annak mindenkori hatályos állapotával kiegészülve. Az online tájékoztatás és felvilágosítás sem 
tartalmilag, sem etikailag nem helyettesítheti a személyre szabott, kommunikáción alapuló orvos-beteg találkozást.

A spamküldők - és néhány gyógyszergyár is - azzal érvelnek, hogy így a lakosság széles rétegeihez jut el az egészségügyi felvilágosítás [7]. A valóságban a cél a minél nagyobb haszonszerzés, és ezt alátámaszthatja az a tény, hogy a gyógyszertárak árukészlete többségében már nem gyógyszer, és az ott kihelyezett plakátok és a töméntelenül sok szórólap egyenesen felszólít az öngyógyításra a gyógyszernek nem minősülő és természetgyógyászati készítményekkel. A médiát pedig elárasztják az OTC-termékek rámenős hirdetéseivel. A betegségükre az orvosnál gyógyulást nem találók (például onkológiai, mozgásszervi betegek) a spamek célközönsége, de a kéretlen levelekből jut bőven a szakembereknek is [8].

$\mathrm{Az}$ ún. „ragadozó” újságokban (raptor, predatory journals) megjelenő „tudományos spamek” (például kongresszusra vagy fizetős cikk írására való felhívások) szakemberekre gyakorolt visszataszító hatását néhány közlemény elemzi ugyan $[9,10]$, az egészségügyi spamek laikusokra való hatását azonban ritkán említik. A jelen közlemény szerzői ezért nemcsak a szakembereknek küldött célzott kéretlen leveleket vizsgálták meg, de az egészségügyet érintő spamek mennyiségi, tartalmi viszonyait és vélhető hatásukat is a laikus közönségre.

\section{Módszer}

Egy éven keresztül gyưjtöttük a levelező szerzőhöz beérkező spameket, melyeket a Windows Outlook Express által használt spamszűrő szürt ki, de beszámítottuk azokat a kéretlen üzeneteket is, melyek kikerülték a szerző munkahelyének szerverei által használt szürőt is, és való- di üzenetként jelentek meg a levelezőmappában. A kapott adatokat év és témakör szerint csoportosítva, a közlemény alapfelvetésének szempontjából osztályozva, az egyszerű leíró statisztika módszerével elemeztük.

Az internetet használó nem kívánt beavatkozásokat az egészségüggyel foglalkozó külföldi szakirodalom kibertámadásokként értékeli [11]. A kibertámadások levélszemét formáját a jelen közleményben az egyén egészségére irányuló és az orvosi-tudományos munkára irányuló beavatkozás/támadás szempontjából vizsgáltuk. Egészséggel összefüggö spameknek tekintettük a készítmények és gyógyszernek nem minősülő termékek és szerek panaceaként való reklámozását (például „Megérkezett az új Varyforte visszér elleni krém, mely megszabadít a visszerek látható tüneteitől, és megelőzi azok újbóli kialakulását”); a gyógyászati segédeszközökre vonatkozó ajánlatokat (például „pontos vérnyomásmérő most zseniális árleszállítással”), a konkrét gyógyításra tett ajánlatokat (például „I mean, insulin dosages reduced by close to $60 \%$ of all patients. And in 16 days no less"); életmódi, egészségnevelésre hasonlító tanácsokat (például „Leadnál még pár kg-ot nyárra? Csokoládés ital súlycsökkentő hatással”).

Felmerül a kérdés, hogy az elemzett orvosi-tudományos munkára irányuló spamek száma és összetétele csak a jelen közleményt író orvosokra, vagy pedig a bármely szakterületen dolgozó orvosokra is érvényes-e? Több kolléga szóbeli tájékoztatásából leszűrhettük azt a következtetést, hogy - fooleg a tudományos munkát végző, közleményeket író kollégák - ugyanilyen jellegü kéretlen leveleket kapnak, sőt nemzetközi fórumokon hasonló tapasztalatokról is beszámoltak.

Mivel az elemzett spamek az első szerző munkahelyi számítógépére érkeztek, nem kizárt, hogy a szerző által

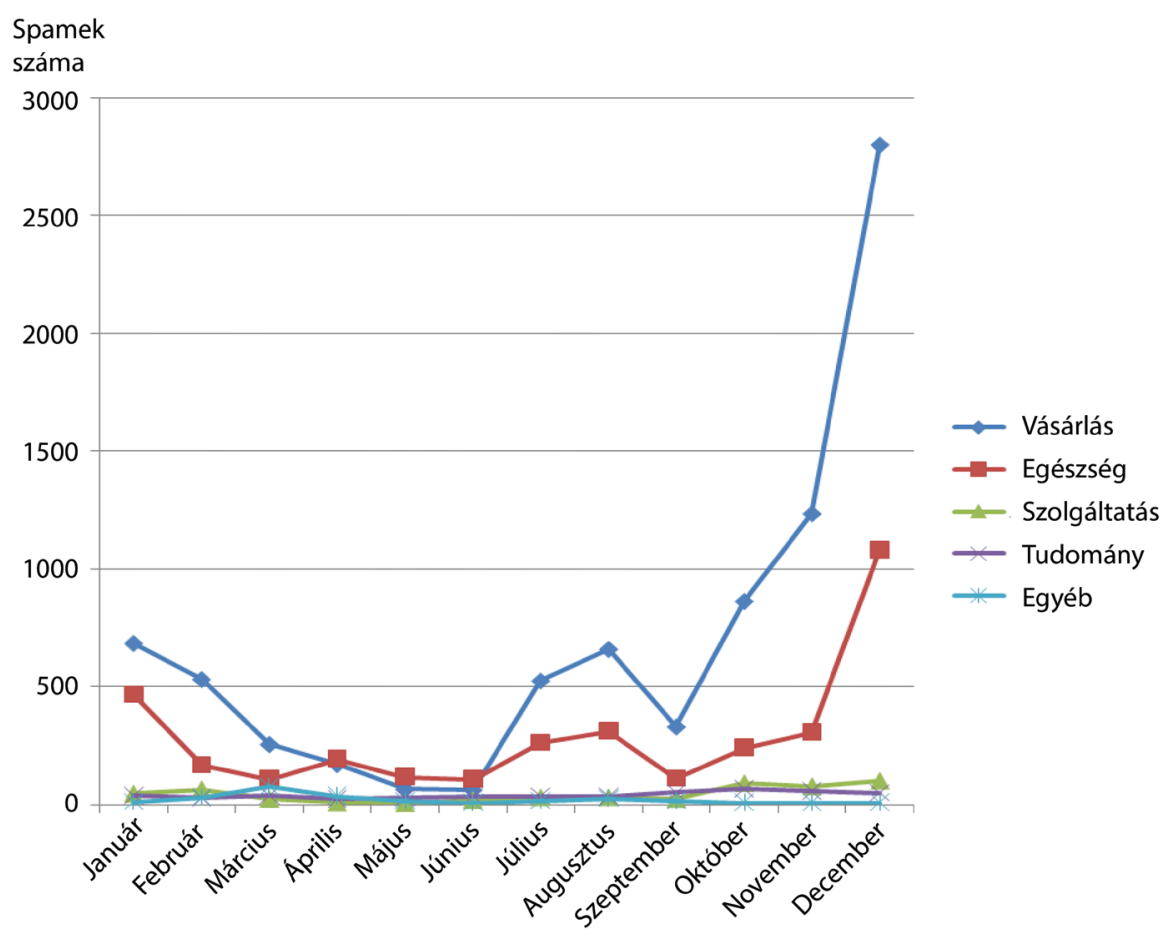

1. ábra

| Az egy éven belül kapott kéretlen levelek havi eloszlása fóbb témakörök szerint 
felkeresett weboldalak (például Google) tartalomfigyelő és adatgyújtő beállítása miatt az érkezett üzenetek egy része az orvosi, illetve a tudományos munkásság miatt került be (például kongresszusra vagy fizetős cikknek az ún. „ragadozó” újságokhoz való beküldésére való felhívás) a spamek közé. Így talán a kongresszusi és cikkírásra felszólító spamek azok, melyek a szerzőt megkülönböztetik a tudományos munkát nem végző orvoskollégáktól.

Azonban az egyén egészségével kapcsolatos kéretlen levelek - melyeknek ártó hatását vélelmezik a szerzők minden internetező gépén megjelenhettek.

\section{Eredmények}

A január 1-jétôl december 31 -ig tartó időszakban összesen 12986 kéretlen üzenetet kaptunk. Az üzenetek havi számát azok tartalma szerint megvizsgálva az 1 . ábrán látható görbét kaptuk.

A spamek nyilvánvaló célja az eladás, és az adatokból világosan kitűnik, hogy az eladni szándékozott árukat az év végi hónapokban fokozottan promotálják, ami érthető dolog karácsony közeledtével. Sajnálatos módon az egészséggel összefüggő ajánlatok is ezt a tendenciát követik, tehát az egészséget mint eladni való árut kezeli a spammer.

Az összes spam témakörök szerinti bontását az 1. táblázatban tüntettük fel.

A jelen közlemény célja a kéretlen e-mail-levelek (spamek) egészségügyet és a gyógyító/tudományos munkát érintő befolyásolási kísérletének elemzése és az annak veszélyeire való figyelemfelhívás. Ezért az általános adatgyüjtés során az ezen területeket érintő spameket vettük szemügyre. Ezeket két csoportba soroltuk: az egészséggel összefüggő (a lakosság egészsége elleni támadás/befolyásolás) spamekre (2. táblázat) és az orvosi vagy a tudományos és gyógyító munka elleni támadásnak/befolyásolásnak értékelhető spamekre (3. táblázat).

\section{Megbeszélés}

Az egészségügy helyzete hazánkban sajnálatos módon ingatag, maga az ellátórendszer a rábízott betegek egészségmegőrzése miatt érzékeny a különböző behatásokra, és mint ilyen, különösen vulnerábilis az internetes befolyásolásra. Minden gyakorló orvoskolléga által tapasztalt jelenség, hogy a beteg a panaszaiból kiindulva „felkészül”, és a neten található diagnózisokat magára vonatkoztatva, az ott említett terápiás javaslatok eltérő voltát kéri számon a kezelőorvoson.

A lakosság saját egészsége iránti fokozott figyelme örvendetes tényező, azonban az egészségnevelést, a betegedukációt, a betegtájékoztatást az internetes információszerzés nem pótolja. Ezért aggasztó, hogy a jelen vizsgálat folyamán az egyén egészségével összefüggő kéretlen e-mail-ajánlatok, mint az az 1. táblázatból kitünik, az összes spam több mint egynegyedét (27\%) tették
1. táblázat |A spamek százalékos megoszlása témakörök szerint

\begin{tabular}{lcc}
\hline Téma & Spamek száma & $\%$ \\
\hline Vásárlás & 8199 & 63 \\
Egészségügy & 3483 & 27 \\
Szolgáltatás & 543 & 4 \\
Tudomány & 492 & 4 \\
Egyéb & 269 & 2 \\
\hline Összesen & 12986 & 100 \\
\hline
\end{tabular}

2. táblázat |Az egészséggel kapcsolatos spamek megoszlása témájuk szerint

\begin{tabular}{|c|c|c|}
\hline Spamtartalom & Összesen & $\%$ \\
\hline Gyógyszerek és természetgyógyászati szerek ajánlatai & 649 & 19 \\
\hline Gyógyászati segédeszközök ajánlatai & 123 & 4 \\
\hline $\begin{array}{l}\text { Konkrét betegség gyógyítására/ tevékenységre tett } \\
\text { ajánlatok }\end{array}$ & 1075 & 31 \\
\hline Masszázs & 609 & 16 \\
\hline $\begin{array}{l}\text { Életmód (fogyás, horkolás, őszülés-, öregedésgátlás } \\
\text { stb.) módszertanának és eszközeinek ajánlása }\end{array}$ & 658 & 19 \\
\hline Szexuális készítmények/ajánlatok & 369 & 11 \\
\hline Egészséggel kapcsolatos spamek - összesen & 3483 & 100 \\
\hline
\end{tabular}

3. táblázat |A tudományos és orvosi munkával összefüggő spamek megoszlása témájuk szerint. Az „egyéb” oszlopban szerepelnek a kéretlen hírlevelek és személyre szóló spamüzenetek

\begin{tabular}{lcc}
\hline Spamtartalom & Összesen & $\%$ \\
\hline Kongresszusi előadásra való meghívás & 133 & 27 \\
Fizetős cikk írására való felhívás & 334 & 68 \\
Egyéb & 25 & 5 \\
\hline Tudomány - Összesen & 492 & 100 \\
\hline
\end{tabular}

ki, és mindjárt a vásárlásra buzdító spamek száma után következtek.

A lakosság egészségével összefüggő spameket témájuk szerint elemezve a helyzet még aggasztóbb: az ezen csoportba gyưjtött levélszemét 31\%-a, mint az a 2. táblázatból kitűnik, a meglévő betegség konkrét gyógyítására (!) vonatkozott. A második leggyakoribb téma az életmódi tanácsokat helyettesítő, a különböző életmódi problémákra - így például horkolás, szkoliózis, fogyás - megoldást nyújtónak kikiáltott eszközök nyílt eladási szándéka sugallta. Mivel ezen egészségi problémák a lakosság nagy részét érintik, és terápiájukban a „hivatalos” alapon álló gyógyítás csak mérsékelt sikert ér el (sokszor a beteg által hosszúnak és gyötrőnek ítélt módszerekkel), érthető, hogy az azonnal ható csodaszereknek és eszközöknek nagy piaca keletkezik, melyet az internetes kufárok lelkiismeretlenül kihasználnak. Az ilyen jellegű spamek ezért a szerzők véleménye szerint nagyon károsak, és ellenük a küzdelmet fel kell venni. 
Külön figyelmet érdemelnek azok a kéretlen levelek, melyek magukat tudományosnak álcázó, magas impaktfaktort hazudó open-access újságokban ( „ragadozó újságok") való közlésre szólítanak fel [12], vagy egyéb, tudományosnak álcázott anyagokkal töltik meg levelezőrendszerünket.

A tudományos érdeklődésnek álcázott kéretlen levelek száma a szerzők anyagában a vizsgált időszakban 492 volt, havonta tehát kb. 4l. Ezek közül közleményírásra 334 (68\%), kongresszusi részvételre 133 (27\%) szólított fel, kéretlen orvosi tárgyú hírlevél, illetve egyéb tartalmú spam $25(5 \%)$ volt. Dán kutatók hasonló eredményre jutottak (havi 45 tudományos spam, ezek között közleményírásra 77\%, kongresszusi felhívásra 19\% érkezett) [12]. Más tudományos kutatók ennél rosszabbul jártak: havi 193 (18\% kongresszusi meghívás, 33\% cikk-küldésre felszólító) spamet, 312 havi (fele-fele arányban kongresszusi meghívások és cikk-küldésre felszólító) spamet kaptak [13].

Ami ezeket a tudományos munkát akadályozó spameket illeti, a külföldi tanulmányok szerzői egyöntetúen arra a következtetésre jutottak, hogy a spamban megjelölt „leiratkozás” lehetőséget (már amennyiben van) választva a spam mennyisége nem csökkent [14]. A világon a küldött e-mailek 80\%-a spam, és növekszik a számuk az egészségügyi praxisban is [15]. A szerzők tapasztalatai szerint az invitálásokra semmiképpen sem szabad reagálni, és az általunk használt Outlook Express spamszưrőjét konzekvensen megtanítva a levélszemét felismerésére, legalább a beérkezett levelek között alig találtunk spameket. Az is igaz, hogy sajnálatos módon a szűrő sok, releváns és fontos értesítést is kiszűrt, így mégiscsak kénytelenek voltunk átfutni a beérkezett levélszemétmappát is.

A mai korszerú elektronikai felderítési módszerekkel a spamküldőket utol lehet érni. Önmagában a Nemzeti Hírközlési Hatóság részére küldött bejelentés (mely bonyolult, időt rabló, és ügyfélkaput igényel [!]) nem oldja meg a kérdést, legfeljebb közigazgatási útra tereli. Az is érthető, hogy az egyetlen spamkapó személy több tucat napi bejelentését sem képes a Hatóság kezelni, nemhogy az összes bejelentő összes napi panaszát. Tehát - főleg az egészséget érintő spamek tekintetében - szigorúbb polgári és büntetőjogi szabályozással lehetne a káros tartalmú, egészséget érintő spamek küldésének elejét venni, hiszen az Európai Unió új adatvédelmi irányelve a spamküldést semennyire sem befolyásolta. Határozottabb egészségpolitikusi fellépéssel és professzionális egészségneveléssel és betegtájékoztatással ezeket az egészséget veszélyeztető spameket talán ki lehetne iktatni az állampolgárok életéből. Ennek hiányában a betegedukáció és a gyógyítás maga is csorbát szenved.

Anyagi támogatás: A közlemény megírása, illetve a kapcsolódó kutatómunka anyagi támogatásban nem részesült.
Szerzői munkamegosztás: F. P.: Kutatómunka, statisztikakészítés, a közlemény megfogalmazása. L. I.: Kutatómunka, a közlemény megfogalmazása. A cikk végleges változatát mindkét szerző elolvasta és jóváhagyta.

Érdekeltségek: A szerzőknek nincsenek érdekeltségeik.

\section{Köszönetnyilvánítás}

A szerzők köszönetet mondanak Nagy Alexandrának a statisztikai elemzés elkészítésében nyújtott munkájáért.

\section{Irodalom}

[1] Haroon MZ, Zeb Z, Javed Z, et al. Internet addiction in medical students. J Ayub Med Coll Abbottabad 2018; 30(4 Suppl 1): S659-S663.

[2] Jones G, Asghar A, Llewellyn DJ. The epidemiology of rockclimbing injuries. Br J Sports Med. 2008: 42: 773-778.

[3] Hamer DH, Connor BA. Travel health knowledge, attitudes and practices among United States travelers. J Travel Med. 2004: 11: 23-26.

[4] Hill DR, Pearson RD. Health advice for international travel. Ann Intern Med. 1988; 108: 839-852.

[5] Sarasohn-Kahn J. Health citizens in emerging countries seek health information online even more than their peers in developed economies. Available from: https://www.healthpopuli. com $/ 2011 / 01 / 06 /$ health-citizens-in-emerging-countriesseek-health-information-online-even-more-than-their-peers-indeveloped-economies [accessed: March 27, 2019].

[6] Mackey TK, Liang BA. Pharmaceutical digital marketing and governance: illicit actors and challenges to global patient safety and public health. Global Health 2013; 9: 45.

[7] Spence D. Spam medicine. BMJ 2008: 337: 178.

[8] Delgado-López PD, Corrales-García EM. Influence of internet and social media in the promotion of alternative oncology, cancer quackery, and the predatory publishing phenomenon. Cureus 2018; 10: e2617.

[9] Dadkhah M, Borchardt G, Maliszewski T. Fraud in academic publishing: researchers under cyber-attacks. Am J Med. 2017; 130: 27-30.

[10] Memon AR. Predatory journals spamming for publications: what should researchers do? Sci Eng Ethics 2018; 24: 1617-1639.

[11] Luna R, Rhine E, Myhra M, et al. Cyber threats to health information systems: a systematic review. Technol Health Care 2016; 24: 1-9.

[12] West N, Sass HC. Scientific spam. Ugeskr Laeger 2018; 180: V70033. [Danish]

[13] Clemons M, de Costa e Silva M, Joy AA, et al. Predatory invitations from journals: more than just a nuisance? Oncologist 2017; 22: 236-240.

[14] Grey A, Bolland MJ, Dalbeth N, et al. We read spam a lot: prospective cohort study of unsolicited and unwanted academic invitations. BMJ 2016; 355: i5383.

[15] Moher D, Srivastava A. You are invited to submit. BMC Med. 2015; 13: 180 .

(Felkai Péter dr., Budapest, Szentendrei út 301., 1039 e-mail: peter.felkai@soshungary.hu)

A cikk a Creative Commons Attribution 4.0 International License (https://creativecommons.org/licenses/by/4.0/) feltételei szerint publikált Open Access közlemény. (SID_1) 